\title{
Regulation of the Welfare of Outsourcing Workers in Banking Companies After the Enactment of the Job Creation Law in Indonesia
}

\author{
Sonhaji ${ }^{1}$, Kadek Cahya Susila Wibawa ${ }^{2}$, Henny Juliani ${ }^{3}$ \\ \{sonhajimuh19@gmail.com¹, kadekwibawa@lecturer.undip.ac.id ${ }^{2}$, hennyjuliani.fhundip@gmail.com ${ }^{3}$ \} \\ Universitas Diponegoro, Indonesia ${ }^{1,2,3}$
}

\begin{abstract}
The enactment of the Job Creation Law has brought significant changes in various fields of law in Indonesia, including changes in labor law, particularly in regulations related to outsourced workers. Several changes related to outsourced workers in the Job Creation Law, among others: related to the absence of restrictions on work that outsourced workers are prohibited from doing; elimination of obligation to appoint employees, and others. This paper aims to examine and describe the crucial arrangements for outsourcing workers in banking companies after enacting the Job Creation Law. Furthermore, this paper will also examine the welfare of outsourcing workers in the banking sector after enacting the Job Creation Law. This research uses doctrinal and nondoctrinal legal research, which is part of qualitative research with descriptive-analytical research specifications. The results show that the fundamental changes in the Job Creation Law have significant implications regarding the existence of agency workers. The Job Creation Law and Gov. Reg. 36/2021 provide directions for changes in the wage system, which are aimed at realizing the welfare of workers, including outsourcing workers in the banking sector.
\end{abstract}

Keywords: Well-being, Workers, Outsourcing, Banking, Job Creation Law

\section{Introduction}

After the legalization of the outsourcing system in Articles 59, 64-66 of Law No. 13 of 2003 concerning Manpower (Labor Law 2003), there have been many responses regarding this policy. This policy has also been submitted for a judicial review to the Constitutional Court because it contradicts Article 27 paragraph (2), Article 28D paragraph (2), and Article 33 paragraph (1) of the 1945 Constitution due to the outsourcing work system in labor policies. Many work agreements did cause injustice, where one party gets an advantage, and the other feels disadvantaged [1]. Some irregularities that occur in the practice of outsourcing, among others: (a) Employer companies do not comply with the conditions set for the types of work that can be outsourced as stipulated in Article 65 paragraph (2) Labor Law 2003 [2], This is due to different interpretations of what types of work may be outsourced [3]; (b) A work agreement that is made not based on an agreement between workers and employers, but is made unilaterally by the employer; (c) Violation of the provisions concerning the time limit for work (vide Article 59 paragraph (1) Labor Law 2003) [4]; and (d) some employers quote money from outsourced workers for various reasons [5]. This problem occurs in almost all sectors, including banking, with outsourcing workers in banking such as contract implementation, wage provision, social 
security provision, welfare facilities provision, etc. In a climate of increasingly fierce business competition, companies are trying to make the cost of production efficiency, and the outsourcing system is one of the solutions to achieve production cost efficiency [6].

Changes in regulations related to the outsourcing system after enacting Law No. 11 of 2020 concerning Job Creation Law/Omnibus Law led to different interpretations. The labor clusters regulated in Chapter IV of the Job Creation Law amend four laws, namely Labor Law 2003, Law No. 40 of 2004 concerning the National Social Security System (SJSN Law), Law No. 24 of 2011 concerning Social Security Administering Bodies (BPJS Law), and Law No. 18 of 2017 concerning the Protection of Indonesian Migrant Workers (UU PPMI) [7]. Several labor clusters in the Omnibus Law have received sharp attention from the public, especially regarding the outsourcing system.

Several things related to the public's spotlight on the outsourcing system after the enactment of the Job Creation Law: there is no limit to outsourcing work, thus removing one's hope of becoming a permanent worker in the company [8]. It means that the Job Creation Law provides opportunities for outsourcing companies to hire workers for various tasks, including freelancers and full-time workers [7]. Another problem relates that the Job Creation Law does not answer the issue of protecting workers from violations of outsourcing practices that have occurred so far, such as violations of wages, working hours, and types of work being outsourced [7].

Several previous studies have been recorded discussing the Job Creation Law, outsourcing workers, and worker welfare (wages). Putra [9] conducted research related to applying the Job Creation Law in regulatory reform efforts. Prabowo et al. [10] showed to solve complicated licensing and overlapping regulations that could hinder investment.

Another research was also conducted by Prabhaputra et al. [11] to focus on the study of the arrangement of the outsourcing system according to Indonesian laws and regulations and the industrial relation to workers in the outsourcing system. Parinduri [6], conducted research related to legal protection for workers in outsourcing work agreements. Catur et al. [8] also conducted research that focused on the relationship between the Job Creation Law as a strategic policy to protect worker welfare. Safitri [12] researched the Omnibus Law of the Job Creation Bill from the perspective of participatory development communication. The results show that the government has not yet conducted participatory communication to the workers and students in drafting the Omnibus Law on the Employment bill. This administration is more inclined to instrumental perspectives where state officials are dominant actors of policy-making processes, which emphasizes the legality aspect of the bills. Based on previous research, this research study focuses on examining and describing crucial arrangements for outsourcing workers in banking companies after the enactment of the Job Creation Law. Furthermore, this paper will also examine the relationship between workers' welfare, especially for outsourcing workers in banking companies, after the enactment of the Job Creation Law.

\section{Research Method}

This research uses a combination of doctrinal legal research and non-doctrinal legal research. This research uses a regulatory approach using secondary data related to doctrinal legal research [13]. In the regulatory (statutory) approach, an analysis is carried out on the 1945 Constitution of the Republic of Indonesia; Labor Law 2003; Government Regulation No. 78 of 2015 concerning Wages (Gov. Reg. 782015); Job Creation Law, Government Regulation No. 
35 of 2021 concerning Specific Time Work Agreements, Transfer, Working Time and Rest Time, and Termination of Employment (Gov. Reg. No. 35/2021); Government Regulation No. 36 of 2021 concerning Wages.

Regarding non-doctrinal legal research using a qualitative approach, analysis of the results of studies to answer the issues was conducted using a qualitative approach. Qualitative research is used to investigate, describe, explain, discover the quality or features of social influence that cannot be explained, measured, or illustrated through a quantitative approach [14]. This research begins by determining the research locations: BNI Pleburan, BNI Tembalang, and BTN Tembalang. Respondents were selected by purposive sampling, with a total of 8 workers in the banking sector. The data was obtained by conducting interviews with the respondents.

\section{Results and Discussion}

\subsection{Regulations Related to Outsourcing Workers after the Establishment of the Job Creation Law}

Outsourcing has long been developing in Indonesia, especially in contracting jobs and carried out for the mining sector. Then outsourcing developed in other sectors can be seen from the Decree of the Minister of Trade of the Republic of Indonesia No. 264/KP/1989 regarding Sub-Contract Management in Archipelago Bonded Zones [2]. Article 64 of the 2003 Labor Law states that the working relationship with the outsourcing system can only be carried out through two forms of work agreements made in writing: charter jobs and worker service providers. In this regard, outsourcing for worker service providers was new when the Labor Law was enacted in 2003. Yasar [15] stated that companies that provide worker services could only provide labor services and take care of human resources and administration, while facilities such as premises, supervisors, and all means of production are in the user's company. Legally and formally, the legitimacy of the implementation of the outsourcing system work relationship is also strengthened by the decision of the Constitutional Court (MK) of the Republic of Indonesia No. 012/PUU-112003 dated October 28, 2004, which basically states that the implementation of the outsourcing system work relationship does not violate the constitutional rights of citizens [2].

In its implementation, the outsourcing system is still problematic when viewed from enacting laws based on legal effectiveness because the law's enactment is based on legal acceptance or recognition of whomever the law addresses [16]. The enactment of the Job Creation Law is expected to bring about changes in regulating agency workers in Indonesia. Some of the fundamental changes related to agency workers in the Job Creation Law include:

1) Article 66 of the Job Creation Law does not regulate the restrictions on the types of work that are prohibited from being carried out by outsourced workers. It means that the Law provides opportunities for outsourcing companies to employ workers in various functions and tasks, including freelancers and full-time workers [7].

2) Articles 64 and 65 of the 2003 Labor Law, which the Job Creation Law deleted, govern work contracting agreements. The government thinks that it does not want to interfere in the realm of business or civil agreements. The government only regulates protecting workers from work agreements that place workers in a vulnerable position when confronted by an employer [7]. 
Further regulations related to outsourcing workers after the stipulation of the Job Creation Law are regulated in Government Regulation No. 35 of 2021. President Jokowi signed this regulation on February 2, 2021, automatically revises the articles governing outsourcing in the 2003 Labor Law.

Article 18 paragraph (1) and (2) Gov. Reg. No. 35/2021 stipulates that: the working relationship between the outsourcing company and the employed workers/laborers is based on a specific time work agreement (PKWT) or an unspecified time work agreement (PKWTT) in written form. This provision is different in the 2003 Labor Law. It is different from the labor law, where the work contract of workers only uses PKWT.

Furthermore, Article 18 paragraph (3) Gov. Reg. No. 35/2021 states that: protection of workers/labor, wages, welfare, working conditions, and disputes that arise are carried out in accordance with the provisions of laws and regulations and are the responsibility of the outsourcing company. Article 18 paragraph (4) Gov. Reg. No. 35/2021 also regulates that worker/labor protection, wages, welfare, working conditions, and disputes that arise are regulated in work agreements, company regulations, or collective working agreements.

Then, Gov. Reg. No. 35/2021 is in line with the Job Creation Law which does not state whether agency workers are still limited to certain types of work or are otherwise expanded. The 2003 Labor Law explicitly states that outsourcing work is limited to jobs outside the main activities or those not related to the production process except for supporting activities. With this revision, labor unions are concerned that the Job Creation Law opens up the possibility for outsourcing companies to hire outsourced employees for various tasks, including freelancers and full-time workers. It will make outsourced personnel more accessible if it is not regulated in government regulations, both in the Job Creation Law and its derivatives regulations [17].

Article 19 paragraph (1) Gov. Reg. No. 35/2021 requires that: if an outsourcing company employs workers/laborers on a non-permanent basis, the work agreement must require the transfer of rights protection for the worker/laborer in the event of a change in the outsourcing company and as long as the object of work remains. It means that the transfer requirements for the protection of workers/laborers' rights guarantee the continuity of work for workers/laborers whose working relationship is based on non-permanent contracts in the outsourcing company. The outsourcing company is responsible for fulfilling workers/laborers' rights if the worker/laborer is not guaranteed continuity of work. Based on this, there are still unresolved legal issues related to outsourcing work after enacting the Job Creation Law and Gov. Reg. $35 / 2021$.

\subsection{Implications of the Establishment of the Job Creation Law on the Welfare of Outsourcing Workers in Banking Companies in Indonesia}

The wage system in the 2003 Labor Law only recognizes the type of minimum wage. It is different in Article 88B of the Job Creation Law, where the new wage system contains wages based on time units and results based on hours. The Minister of Manpower, Ida Fauziyah, explained that the new regulation aims to accommodate the needs of the business sector which require flexibility in the workforce wage payment scheme which has no legal basis in Indonesia [18].

The Job Creation Law removes Provincial Sectoral Minimum Wages (UMSP) and District/City Sectoral Minimum Wages (UMSK). The stipulation of the provincial minimum wage is regulated and stipulated by the Governor based on economic and employment conditions with certain conditions [7]. It is different from the provisions in Article 89 of the 2003 Labor Law, which stipulates that the minimum wage is determined based on sectoral 
wages and wages at the provincial level and wages at the district/city level, which are directed at the district/city level achieving life worthiness [7]. Furthermore, this provision regulates that the Governor determines the provincial minimum wage by considering the recommendations from the Provincial Wage Council and/or the Regent/Mayor. Meanwhile, the calculation of components and implementing the stages of achieving the need for a decent life shall be regulated by a Ministerial Decree [7].

The implication of eliminating the sectoral minimum wage results in no difference in wages based on expertise specifications per field or sector to illustrate: the minimum wage for workers in the clothing or food sector is equated with the value of the minimum wage for workers in the banking sector. Workers in the convection or food sector have different specifications from workers in the banking sector. As practiced in various countries, the sectoral minimum wage applies according to the value-added contribution of each industry to Gross Domestic Product [19]. Furthermore, Job Creation Law also stipulates that the minimum wage provision is exempted for SME entrepreneurs and is determined based on an agreement between employers and workers in the company and changed the components of the structure and scale of wages in companies by taking into account class, position, years of service, education, and competence.

The birth of Gov. Reg. No. 36/2021 is the beginning of a new wage system based on the Job Creation Law. Article 4 and Article 5 of Gov. Reg. 36/2021 emphasize that the wage policy is established 'to realize workers' rights to a decent life for humanity. There are five crucial points in wage arrangements regulated in Gov. Reg. No. 36/2021, including [20]:

1) Employers are prohibited from paying wages below the stipulated minimum wage, and the minimum wages are determined based on economic and employment conditions.

2) Entrepreneurs are required to prepare and implement a structure and scale of wages in the company by considering the company's capabilities and productivity.

3) Wages for micro and small enterprises are determined based on an agreement between the entrepreneur and the workers/laborers in the company with the provision that they are at least $50 \%$ of the average consumption of the people at the provincial level; and an agreed wage rate of at least $25 \%$ above the poverty line at the provincial level.

4) Overtime wages must be paid by employers who employ workers over working hours or on weekly breaks or are employed on official holidays as compensation to the workers concerned in accordance with the provisions of laws and regulations.

5) Wages are not paid if the worker does not come to work and/or does not work unless the worker is absent, do other activities outside of his job, exercises his right to rest or leave; or willing to do the work that has been promised but the entrepreneur does not employ it because of the entrepreneur's own fault or an obstacle that the entrepreneur could have avoided.

Regarding outsourcing workers in banking companies with working relationships with service providers, the latest wage provisions also apply in industrial relations between banking outsourcing workers and service providers. Outsourcing companies must comply with the provisions stipulated in the wage policy in the Job Creation Law and Gov. Reg. No. 36/2021.

Companies are obliged not to pay workers' wages in the banking sector below the minimum wage, let alone pay attention to companies' ability to use outsourcing workers (banking) that have good financial capabilities, so in preparing and structuring and scale wages must be fair for agency workers. Employers are still required to pay overtime wages for outsourcing workers, including in the banking sector, based on the provisions of Gov. Reg. No. 36/2021. Based on these regulations, BNI Pleburan, BNI Tembalang, and BTN Tembalang have a strong commitment to pay overtime wages for their outsourced workers. 


\section{Conclusion}

Based on this description, the conclusions that can be drawn are: there are several differences in principles related to the regulation of outsourcing workers in the 2003 Labor Law and the Job Creation Law. The fundamental thing related to outsourcing workers relates to the types of agreements that underlie the working relationship in the outsourcing system, namely: a specific time work agreement (PKWT) or an indefinite time work agreement (PKWTT) in written form. Concerning wages, the wage system after the Job Creation Law and Gov. Reg. No. 36/2021 states that the minimum wage is determined based on economic and employment conditions; employers are obliged to prepare and implement the structure and scale of wages in the company by taking into account the company's capabilities and productivity. This provision provides certainty for outsourcing workers in the banking sector that the welfare of workers is guaranteed in-laws and regulations.

\section{Acknowledgements}

The author would like to thank the Faculty of Law, Universitas Diponegoro, for facilitating the author to participate in the $2^{\text {nd }}$ International Conference on Law, Economic, and Governance 2021.

\section{References}

[1] N. Nafila, E. Kristine, and E. Wijaya, "Perlindungan Hak-Hak Buruh Pada Praktik Sistem Outsourcing: Sebuah Kesenjangan Penerimaan,” J. Huk. Nov., vol. 8, no. 2, pp. 252-268, 2017.

[2] Triyono, "Outsourcing Dalam Perspektif Pekerja Dan Pengusaha," J. Kependud. Indones., vol. VI, no. 01, pp. 45-62, 2011.

[3] S. L. Utomo, "Permasalahan Outsourcing dalam Sistem Ketenagakerjaan di Indonesia," Lex Publica, vol. 01, no. 01, pp. 1-10, 2014.

[4] S. Kunarti, "Perjanjian pemborongan pekerjaan (outsourcing)," J. Din. Huk., vol. 9, no. 1, pp. 67-76, 2009.

[5] A. Munir, "Viktimisasi Struktural terhadap Buruh Melalui Sistem Outsourcing (Studi Kasus Buruh Outsourcing PT (X) yang Dipekerjakan pada PT (Y) di Kabupaten Serang, Provinsi Banten)," Sosiol. J. Ilm. Kaji. Ilmu Sos. dan Budaya, vol. 16, no. 2, pp. 77-92, 2014.

[6] A. S. Parinduri, "Perlindungan Hukum Bagi Tenaga Kerja Dalam Perjanjian Kerja Outsourcing," RESTITUSI J. Mhs. ILMU Huk., vol. 1, no. 1, pp. 83-103, 2019.

[7] E. D. Arifanti and Nabila, Kertas Advokasi Kebijakan Atas UU No 11 Tahun 2020 Tentang Cipta Kerja Bidang Ketenagakerjaan. Jakarta, 2020.

[8] J. S. Catur et al., "Perlindungan Hukum Terhadap Kesejahteraan Pekerja Melalui UndangUndang Nomor 11 Tahun 2020 Tentang Cipta Kerja," J. Lex Spec., vol. 1, no. 2, 2020.

[9] A. Putra, "Penerapan Omnibus Law dalam Upaya Reformasi Regulasi," J. Legis. Indones., vol. 17, no. 1, pp. 1-10, 2020.

[10] A. S. Prabowo, A. N. Triputra, Y. Junaidi, and D. E. Purwoleksono, "Politik Hukum Omnibus Law di Indonesia," Pamator J., vol. 13, no. 1, pp. 1-6, 2020.

[11] A. A. Prabhaputra, I. N. P. Budiartha, and I. P. G. Seputra, "Sistem Outsourcing dalam Hubungan Industrial di Indonesia (Outsourcing System In Industrial Relation In Indonesia),” J. Analog. Huk., vol. 1, no. 1, pp. 22-27, 2019.

[12] D. Safitri, "Omnibus Law RUU Cipta Lapangan Kerja dalam Perspektif Komunikasi Pembangunan Partisipatf," J. Dialog Kebijak. Publik, vol. 23, 2020. 
[13] K. C. S. Wibawa and A. Putrijanti, "The Reconstruction of Public Information Dispute Resolution as the Effort in Realizing Substantive Justice in Indonesia," J. Environ. Treat. Tech., vol. 9, no. 1, pp. 110-116, 2021.

[14] S. N. Susanto and K. C. S. Wibawa, "The Existence of The Indonesia Peatland Restoration Agency in Perspective of Organization and Authority," Adm. Law Gov. J., vol. 3, no. 1, pp. 92103, 2020.

[15] I. Yasar, “Merancang Perjanjian Kerja Outsourcing,” Jakarta PPM Manaj., 2009.

[16] J. Fitriyaningrum, "Implementasi Sistem Alih Daya atau Outsourcing Dalam Mencapai Kesejahteraan Pekerja Indonesia Ditinjau Dari Undang-Undang Nomor 13 Tahun 2003," Indones. State Law Rev, vol. 22, no. 1, pp. 88-102, 2019.

[17] M. Idris, "Begini Nasib Karyawan Outsourcing di Peraturan Terbaru Jokowi," Kompas.com, 2021. https://money.kompas.com/read/2021/03/01/093456026/begini-nasib-karyawanoutsourcing-di-peraturan-terbaru-jokowi?page=all. (Accessed May 10, 2021).

[18] Ihsanuddin, "Jokowi Bantah Upah Minimum Dihitung Per Jam di UU Cipta Kerja, Bagaimana Faktanya?," Kompas.com, 2020. Jokowi Bantah Upah Minimum Dihitung Per Jam di UU Cipta Kerja, Bagaimana Faktanya? (Accessed May 10, 2021).

[19] CNN Indonesia, "Rincian Aturan Upah Pekerja dalam Omnibus Law Ciptaker," CNN Indonesia, 2020. https://www.cnnindonesia.com/ekonomi/20201006164645-532-555075/rincian-aturanupah-pekerja-dalam-omnibus-law-ciptaker (accessed May 10, 2021).

[20] T. Santia, "PP 36 Tahun 2021: Pengusaha Dilarang Bayar Gaji di Bawah Upah Minimum," Merdeka.com, 2021. https://www.merdeka.com/uang/pp-36-tahun-2021-pengusaha-dilarangbayar-gaji-di-bawah-upah-minimum.html (accessed May 10, 2021). 